\title{
DMSP/OLS night-time light imagery for urban population estimates in the Brazilian Amazon
}

\author{
S. AMARAL*†, A. M. V. MONTEIRO $\dagger$, G. CAMARA $\uparrow$ and \\ J. A. QUINTANILHA \\ $\dagger$ Instituto Nacional de Pesquisas Espaciais (INPE), Divisão de Processamento de \\ Imagens (DPI), C.P. 515, São José dos Campos, São Paulo, 12201-970, Brazil \\ †Escola Politécnica da Universidade de São Paulo (POLI-USP), Av. Almeida Prado, \\ Trav. 2n 83, São Paulo, S. P., 05508-900, Brazil
}

(Received 7 July 2004; in final form 12 April 2005)

\begin{abstract}
This article analyses DMSP/OLS night-time imagery as an information source to detect human settlements and to estimate the urban population in the Amazon region. DMSP/OLS single orbits were used to generate a DMSP stable light mosaic for 2002, in which most of the urban settlements with a population higher than 5000 inhabitants were precisely identified. DMSP/OLS night-time mosaic images from 1995, 1999 and 2002 were integrated with the IBGE census data and the correlation between DMSP/OLS night-time light area and the urban population was compared. Coefficients of determination higher than 0.8 were obtained from the linear regression between DMSP/OLS night-time lights and urban population census data. Although the fieldwork showed that DMSP image data could only record urbanized settlements with more than $2.5 \mathrm{~km}^{2}$ of well-lit surface areas, the initial and final extension of the night-time light foci were actually precisely registered. Therefore, this paper identifies the potential of DMSP night-time light images for estimating urban population as well as the technical limitations of using such images as a means to monitor urban population dynamics annually in a region where data are scarce and the demographic dynamics are unique, as in the Brazilian Amazon.
\end{abstract}

\section{Introduction}

The Brazilian Amazon occupies 5 million $\mathrm{km}^{2}$ and comprises the largest preserved and contiguous tropical rain forest in the world: a forested area of approximately 4 million $\mathrm{km}^{2}$. In the last decades, the region has experienced intense transformation processes in both physical and human aspects. Deforestation studies estimated a rate of $25400 \mathrm{~km}^{2}$ of forest conversion for the 2001 to 2002 period (INPE 2003). Additionally, the Legal Amazon ${ }^{1}$ in the 2000 official Census showed to have was 21.1 million inhabitants or $12.4 \%$ of the total Brazilian population, in contrast to $5.8 \%$ in 1950 (SUDAM/PNUD 2001).

The importance of Amazon forest in the dynamics of climatic and biogeochemical processes makes the deforestation of the Amazon a frequent subject of study,

*Corresponding author. Email: silvana@dpi.inpe.br

${ }^{1}$ The Brazilian Legal Amazônia comprises all the states of the north region (Amazonas, Pará, Acre, Rondônia, Roraima, and Amapá), the states of Mato Grosso, Tocantins and part of the state of Maranhão. 
especially with regard to carbon cycling, global climate and environmental changes (Potter et al. 2001, CPTEC/INPE 2003, Roberts et al. 2003, Durieux et al. 2003, Ballester et al. 2003) and the conservation of biodiversity (Fearnside 2001). In contrast, only a relatively small number of researchers are concentrating on the human dimension of the Amazonian occupation. Demographic density, as an example, is usually indicated merely as one of a series of variables to explain the deforestation process (Geist and Lambin 2001, Wood and Skole 1998). Existing studies have shown that the growth in urban population has not come with an improvement in the quality of life of local populations, as observed by the low indexes of health, education and income (Becker 1995, 1998, Browder and Godfrey 1997, Monte-Mór 1998). Thus, the quality of human life in Amazon cities and settlements can be considered one of the major, if not the worst environmental problem in the region (Becker 2001).

The pattern of human population growth in the Amazon region has been similar to the Brazilian population in other urban and rural areas, including an intense urbanization process. In 1970, the urban population corresponded to $35.5 \%$ of the total population in the region. This value increased to $58 \%$ in 1991 and reached $69 \%$ in 2000 (IBGE 2001). The diversification of economic activities and the changes in the population network reorganized the structure of the human settlements, leading to the term 'urbanized forest' to designate the Amazon region (Becker 1998).

Sustainable development of the Amazon region is a real issue which must take into account both ecological and human demands, offering a very real challenge for the world of science. Within this context, remote sensing data and techniques have contributed significantly to the integration of the ecological and human dimensions. Thus remote sensing is used to understand changes in the land cover/land use in the Amazon region (Frohn et al. 1996, Wood and Skole 1998). Demographic concepts and methods have also used remote sensing to explain different land use/cover patterns, but on a household scale to map local changes (Moran et al. 1994, 2003, Moran and Brondizio 1998, McCracken et al. 1999).

For modelling purposes on a regional scale, information to describe the human population and distribution is scarce. Demographical data are restricted to the decennial census and some annual estimates based on statistics (PNADs) for some metropolitan regions that do not cover the whole Legal Amazon. Remote sensing data, especially from night-time light imagery, has been pointed out as an alternative source of information to identify urban settlements and, indirectly, to characterize human population distribution (Sutton et al. 1997, Elvidge et al. 1997a).

Using night-time light imagery from the Defense Meteorological Satellite Program/Operational Linescan System (DMSP/OLS) in the Amazon region, it was possible to efficiently detect human presence, such as urban settlements and light-demanding activities such as mining and civil construction (Amaral et al. 2005). In addition, electrical power consumption, urban area extension and urban population related linearly to the DMSP night-time lights. Amaral (2003) considered that DMSP night-time light imagery generated from a more representative time series would more precisely represent the urban population distribution.

This article analyses DMSP/OLS night-time imagery as an information source to detect human settlements and to estimate the urban population in the Amazon region. To reach this goal, recent DMSP/OLS single orbits were used to generate new DMSP stable light mosaics. These mosaics were integrated into the IBGE 
census data and a comparative procedure was used to investigate possible correlations between DMSP/OLS night-lights and the urban population data and statistical projections. The ultimate objective was to identify the potential of DMSP night-time light images for estimating urban population as well as the technical limitations of using such images as a mean to monitor the urban population dynamics annually in a region where fieldwork is very costly, and the census data are scarce.

\section{The DMSP/OLS and human activity detection}

The US Air Force Defense Meteorological Satellite Program (DMSP) has been in operation since the 1970s. The Operational Linescan System (OLS), onboard the DMSP satellites, is an oscillating scan radiometer, originally developed for global meteorological forecasting for the US Air Force, capable of detecting visible and thermal-infrared emissions. Using a photomultiplier tube (PMT) at night, the visible spectral band $(0.47-0.95 \mu \mathrm{m})$ makes the sensor very sensitive to faint visible and near-infrared (VNIR) emission sources (Elvidge et al. 1997b) such as those produced by the night-time light of cities, towns, fires, lightning, etc. The spatial resolution of $2.8 \mathrm{~km}$ at full mode, and $0.56 \mathrm{~km}$ at fine mode, associated with approximately $3000 \mathrm{~km}$ of swath, enables the synoptic coverage of large areas. The high contrast between lighted and unlighted areas and the sensor's spatial resolution makes it a useful tool to identify regions of intense human activity (Croft 1973, 1978).

Early attempts to use a single data acquisition of DMSP/OLS imagery to map the distribution of human settlements and the spatial distribution of human activities, such as energy consumption, were hampered due to problems of pixel saturation and blooming, cloud cover, and the presence of ephemeral light sources such as lightning and fires (Welch 1980, Foster 1983, Welch and Zupko 1980). The National Oceanic and Atmospheric Administration (NOAA)/National Geoscience Data Center (NGDC) developed a methodology to produce stable light datasets that solved the problem with ephemeral lights and cloud cover. This method includes the collection, rectification and aggregation of a large number of night-time OLS images. The analysis of the image time series distinguishes stable lights produced by cities, towns and industrial facilities from ephemeral lights. This methodology also accounts for cloud screening and ensures sufficient cloud-free observations to determine the location of all VNIR emissions (Elvidge et al. 1997b). The result is an image whose values are percentages of night-time light occurrences for each pixel. Elvidge et al. (1997a) mapped the US cities in $1 \mathrm{~km}$ resolution cells, obtained from the occurrence of night-time lights of at least $10 \%$ of cloud-free observation (from a total of 236 DMSP/OLS images). The city boundaries were enlarged, which was attributed to the effects of pixel geolocation, light detected on a subpixel scale, and the presence of fog or sparse clouds.

To restrict urban area mapping by using the night-time light images, Imhoff et al. (1997a) suggested an algorithm with a spatial integrity threshold to reduce pixel blooming and saturation. The process consists of identifying the lowest threshold value in the urban/not urban classification that maintains the urban core as a unit. In this case, only pixels detected as night-time lights within $89-100 \%$ from the total of the images were considered as urban areas. Compared with the urban areas from the 1990 US Census, the urban area from DMSP night-time light was only 5\% smaller. Using the same dataset and procedures, Imhoff et al. (1997b) observed that $2.67 \%$ of the US land mass was classified as urban area, much of which was located 
on fertile soil that was ideally suited for agriculture. These results suggested the potential use of DMSP night-time light images for global studies of urbanization, population, and even agricultural productivity constraints.

DMSP night-time light images were also used in regard to human population density relations. Sutton et al. (1997) obtained a quantitative relationship between the intensity of DMSP night-time light (not the percentage of night-time light occurrence for a cloud-free pixel) and the population density for cities of the continental United States. Densely populated urban areas presented pixel saturation in the DMSP night-time light image. The linear regression between population density and DMSP night-time images produced a coefficient of determination $\left(R^{2}\right)$ of 0.84 . For an exponential regression, the same coefficient resulted in 0.93 . In general, DMSP night-time lights underestimated the population density in the urban centers and overestimated the density in suburban areas. The authors suggested the use of DMSP/OLS data not to estimate population density, but to indicate the presence of human activity as in human population distribution models, by building a smart interpolator on a global scale. Sutton (1997) attempted to model the population density inside urban nuclei, having DMSP night-time light intensity as the reference of the urban area, using different decay functions. Urban density models were parameterized from the size and shape of the urban nuclei and from the log-log relation between the urban area and population density obtained from Sutton et al. (1997).

DMSP night-time imagery was also suggested as a feasible alternative to identify urban settlements on a global scale (Elvidge et al. 2001a). Lighted areas were correlated with population, gross domestic product (GDP) and energy consumption of 21 countries with different economies. Linear relations with populations produced $R^{2}=0.85$, where the outliers were countries with poor economies. Similarly, electrical power consumption and gross domestic product resulted in $R^{2}=0.96$ and $R^{2}=0.97$, respectively. These results suggested that DMSP/OLS imagery could be used to infer global population spatial distribution, with a proper regional or national calibration. Doll et al. (2000) have observed that night-time light data were related to carbon dioxide emission parameters on a global scale, as a proxy of development and urbanization with a statistically significant correlation with GDP and total carbon dioxide emission.

DMSP/OLS data have also been used to indicate variables of spatial distribution of human activity in simulation models. Using the gravitational model of spatial interactions with variables such as accessibility and population density in a geographical information system, Plutzar et al. (2000) simulated some patterns of night-time light evolution as a reference for the evolution of socioeconomic activities in China. The authors emphasized the applicability of DMSP/OLS data as an ancillary tool for planning infrastructure and electrical power demand on a regional scale.

DMSP/OLS data have also been indicated as a valuable information source to distribute the population into density surfaces (Turner and Openshaw 2001). Using a worldwide population database, DMSP/OLS data have been used to estimate populations at risk, as in the LandScan Project (Dobson et al. 2000). The distribution of the population in the LandScan project represents an ambient population, including diurnal movements and collective travel habits in a single measure. DMSP night-time light, associated with road proximity, slope and land cover, defined the probability coefficients that assigned available census counts in a population density surface for the entire world. 
Given their nature and spatial resolution, the DMSP night-time light images are the most suitable data source to represent urban concentration and expansion on continental and global scales (Elvidge et al. 2001a). The evaluation of the level of development for the largest river basins in the world, presented by The World Resources Institute (Revenga et al. 1998), is an example of the use of DMSP nighttime light data on a global scale.

On a regional scale, DMSP/OLS data were recently evaluated to analyse human presence and human activities in Brazilian Amazonia (Amaral et al. 2005). DMSP night-time light images were related to human presence and activity in the region. A linear relation $\left(R^{2}=0.79\right)$ was obtained between urban population from the Census data and DMSP night-time light for the state of Pará, Brazil. Similarly, electrical power consumption was linearly correlated with DMSP night-time light foci. Thus, the DMSP/OLS data may be used as an indicator of human presence in the analysis of spatial-temporal patterns in the Amazonian region.

\section{Data and methods}

\subsection{DMSPIOLS night-time light mosaic images}

Two DMSP night-time light mosaic images were provided by the NGDC/NOAA, referring to the period of 1994-1995 and 1999, and a more recent mosaic image was generated, referring to 2002 .

The analysis presented in this work was based on the percentage of orbits with night-time light detected for the total cloud-cover-free pixels. This criterion was chosen first due to the unavailability of a calibrated image of light intensity for single orbits. Second, the DMSP/OLS night-time light mosaic images available (for 1994-1995 and 1999) were generated based on this criterion. To accomplish a temporal analysis and comparison with population census data, the same criterion was defined to generate a recent night-time light mosaic image.

The DMSP 2002 mosaic image resulted from the mosaic of 61 DMSP/OLS nighttime light images obtained from the new moon period from January to June. All the night-time light single-pass images were obtained by the DMSP/F15 satellite, received by the Air Force Weather Agency (AFWA) and recorded by the National Geophysical Data Center's Solar Terrestrial Physics Division (NGDC/STP). This database was accessed and pre-processed by the Instituto Brasileiro do Meio Ambiente e dos Recursos Naturais Renováveis (IBAMA). The preprocessing consisted of geolocation and stable light detection procedures, developed by NGDC for monitoring fires (Elvidge et al. 2001b). The VNIR emission sources and cloud pixels were geolocated and identified in a reference grid generated by each orbit. The digital number (DN) of these grids was represented by the target classes of clouds, night-time lights and glare (table 1) in each geolocated pixel for each single pass image. These grids were called flag images.

The flag images were then used to compute the frequency of night-time lights, free of cloud occurrence (DN 2 in the flag image), in every pixel of the grid. Similarly, the occurrence of pixels that were cloud-cover-free was counted (DN 0 and 2 in the flag image), and the total frequency of both light and cloud-cover-free pixels produced two new grids: a cloud coverage frequency image and a night-time light frequency image. The total light frequency was then divided by the total cloud-free frequency for the analysed period and multiplied by 100. The result was the percentage of VNIR detected for each grid cell, considering only the cloud-free coverage OLS 
Table 1. Correspondence between the digital number (DN) and the target classes identified in the flag images.

\begin{tabular}{lc}
\hline DN & Target class \\
\hline 0 & No cloud and no light \\
1 & Cloud \\
2 & Light \\
3 & Cloud and light \\
4 & Glare \\
5 & Cloud \\
255 & Bad value \\
\hline
\end{tabular}

records (Elvidge et al. 1997a), thereby constituting the night-time light mosaic image.

The presence of low DN values, indicating a low percentage of light occurrences on the DMSP mosaic, produced a noisy aspect in the image. Considering previous analyses of percentages and thresholds (Imhoff et al. 1997b, Henderson et al. 2003, Amaral et al. 2005), DNs lower than 30 were removed from the mosaic image. This represented a satisfactory compromise between the night-time light related to human presence, such as the municipal centers, and the isolated pixel that can be considered as noise since it cannot be related to any human activity in the study of the Amazon region (e.g. most probably from forest fires).

Even though the single DMSP/OLS single orbits used for the mosaic were related to a period of officially low rates of vegetation fire in the Amazon region, some intense fire activities were registered as night-time light. To remove this feature from the DMSP night-time lights mosaic images, the IBAMA/INPE Database for Vegetation Fires (http://www.dpi.inpe.br/proarco/bdqueimadas/) was consulted, and semi-automatic editing was performed on the DMSP mosaic images. The absence of ephemeral night-time light as vegetation fires is essential for the proper use of the DMSP mosaic images of night light to explore its relations to population and human activity in the Amazon region.

\subsection{DMSP mosaics and urban population analysis}

First, in order to analyse the DMSP mosaic images as related to urban area, auxiliary data were added to the database, using Geographical Information System facilities. The geographical coordinates of the urban centres, or districts, provided by the Brazilian Institute of National Statistics and Geography (IBGE), were overlaid as point data references. Remote sensing images available at Mosaico do Brasil (MCT 2003) supplied land cover information from higher spatial resolution sensors (Landsat TM and JERS images) to provide information about night-time light regions not related to any urban centres.

Every pixel with DN greater than 30 was classified as night-time light on the DMSP-2002 image. From this classified image, polygons were drawn as night-time light foci, and a buffer zone of $4 \mathrm{~km}$ from the foci limits defined the analytical units for this study. An analytical unit (AU) determined the zone inside which any human activity that emitted night-time light could be detected. This strategy eliminated problems with image or data registration that might have been present between DMSP mosaic images (for 1995, 1999 and 2002), and even with point data of the urban centres. The total number of DMSP night-time light pixels with DN greater 


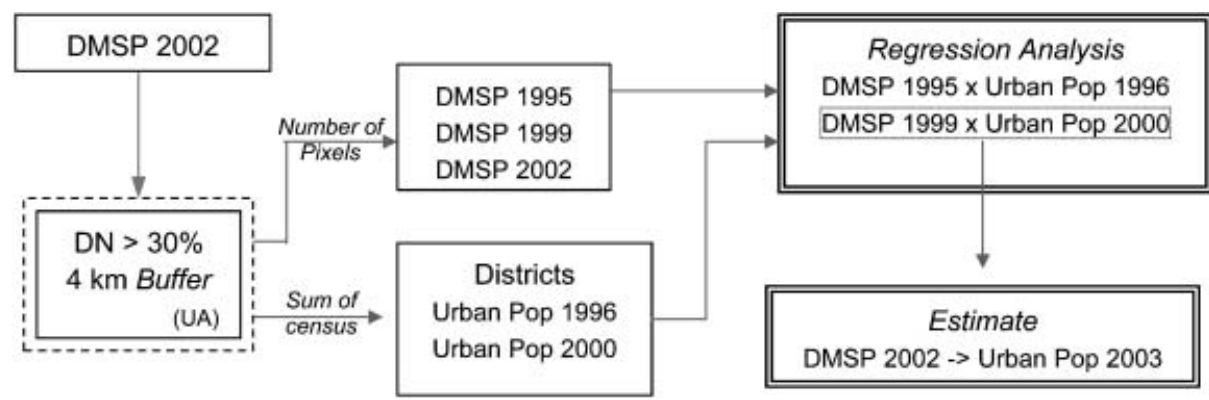

Figure 1. Procedure to explore DMSP night-time lights and urban population relations.

than 30 was computed for every analytical unit for DMSP-1995, DMSP-1999 and DMSP-2002 mosaic images. Then, the urban population count for all districts that were located inside each AU was tallied, considering the IBGE census of 1996 and 2000. Finally, regression analyses were performed considering the night-time light area and urban population estimates for the analytical units, as presented in figure 1. The linear regression analysis explored the relations between DMSP-1995 and the urban population of 1996, and DMSP-1999 and the urban population of 2000.

Then, given the equation resulting from the linear regression for DMSP-1999, the urban population was estimated for DMSP-2002. This result was compared with the demographic data available: the urban population projections for 2003. The population projections were published by IBGE (2003), based on previously published inter-census growth rate tendencies (IBGE 2002).

\section{Results}

\subsection{DMSPIOLS and urban nuclei}

Figure 2 presents the DMSP-2002 image and the cloud cover frequency image, used to compute the percentage of night-time light, the DN pixel value for the DMSP-2002.

(a)

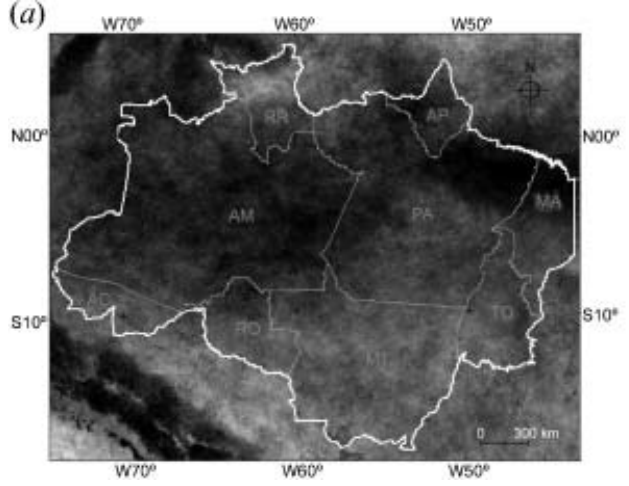

(b)

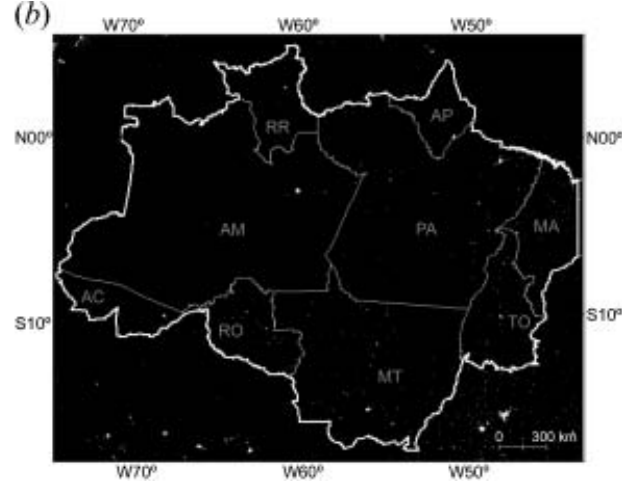

Figure 2. Mosaic images for 2002: (a) cloud cover frequency image with DN referring to the numbers of days $(0-58)$ free of cloud coverage; $(b)$ night-time light mosaic image with DN referring to the percentage $(0-100)$ of night-time light detected for the total cloud-cover-free pixels. 
Even though Amazonia is one of the regions with the most intense cloud cover, as indicated by the dark pixels in figure $2(a)$, it was possible to compare the night-time light foci and the geographical coordinates of the districts. Considering the urban population obtained for each district in the 2000 IBGE census, the following was observed:

(1) One hundred per cent of the districts with urban population higher than 20000 inhabitants (112 districts) were located inside an AU.

(2) From the total of 110 districts with an urban population between 10000 and 20000 inhabitants, only five were not inside a AU. Arame (urban population of 11461 inhabitants) and Pio XII (urban population of 12944 inhabitants), both in the state of Maranhão, and Breu Branco (urban population of 15952 inhabitants), in the state of Pará (PA), when examined on Mosaico do Brasil (www.dpi.inpe.br/mosaico), were districts with inaccurate geographical coordinates. The exact geographical coordinates were checked on topographical maps (1:250 000 scale). In Terra Santa, PA (urban population of 10965 inhabitants), the electrical power is provided by a thermal electric power plant and so the night-time lights are sometimes intermittent. Finally, in Viseu, PA (urban population of 11558 inhabitants), the electrical power consumption for public illumination showed a much lower value $(74.12 \mathrm{kWh})$ compared with districts with similar urban populations in the state $(909.07 \mathrm{kWh})$, indicating reduced illumination infrastructure.

(3) Out of the total of 169 districts with urban populations between 5000 and 10000 inhabitants, $82 \%$ were located inside an AU. Most of these districts were in the states of Pará and Maranhão in a region of high frequency of cloud cover.

(4) Out of the 613 districts with an urban population of less than 5000 inhabitants, only 35\% appeared within an AU (219 districts).

Compared with a previous study of DMSP-1999 (Amaral et al. 2005), a larger number of urban nuclei was detected by the DMSP-2002 mosaic image (575), within smaller urban population classes. While the DMSP-2002 mosaic was able to detect urban nuclei in the 5000 to 10000 urban population class, DMSP-1999 only detected the majority of the urban nuclei within the 20000 to 50000 urban population class. The difference in the number of single orbits used to generate the image mosaic (16 images for DMSP-1999 and 61 for DMSP-2002) and the frequent cloud cover in the Amazon region may explain this discrepancy.

DMSP mosaic images were compared based on the total of night-time light pixels higher than 30\% computed for each AU for DMSP-1995, DMSP-1999 and DMSP2002. The expected intensification of night-time light pixels over the period can be observed in figure 3. However, this result has to be interpreted with caution, since the DMSP mosaic images were produced with an increasing number of single orbits. With a greater number of single orbits, the ability to detect night-time lights in DMSP mosaic images increases because the chance of obtaining a pixel free of cloud cover is higher. Thus, the increase in the number of night-time light pixels cannot be interpreted as unique evidence for new urban nuclei.

A total of 516 AUs was obtained (with a $4 \mathrm{~km}$ buffer zone from night-time light frequency higher than 30\%) from the DMSP-2002 night-time light mosaic image. For DMSP-1999, a total of 280 AUs registered night-time light pixels, 248 of these 


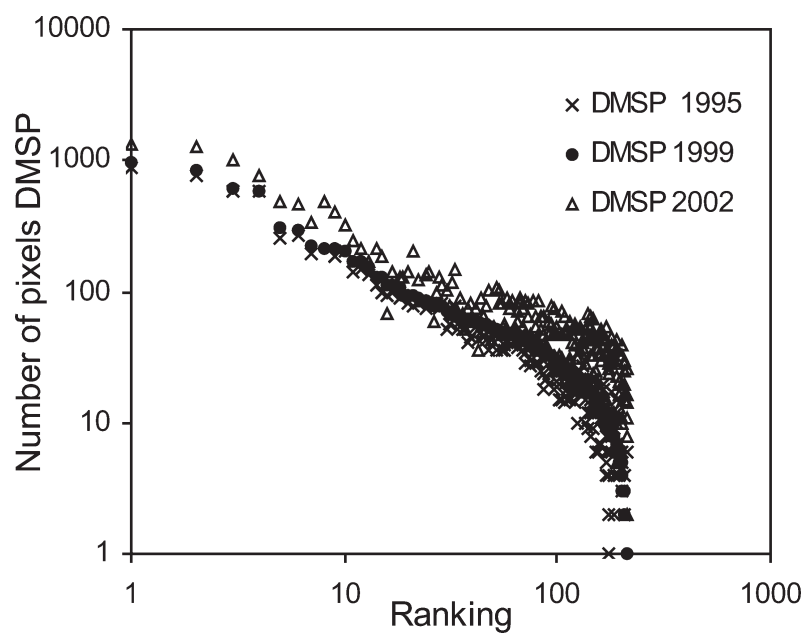

Figure 3. Number of night-time light pixels with DN higher than 30 for each analytical unit in DMSP night-time image mosaics for 1995, 1999 and 2002.

being related to districts with urban populations; the remaining 32 were related to small villages, and other locations that require illumination without a resident population associated with them, such as mining sites.

For DMSP-1995, night-time light pixels were registered in 243 AUs, 226 of which had an associated urban population, according to the IBGE 1996 census.

\subsection{DMSP and urban population estimates}

The linear regression analysis for DMSP-1995 with the urban population 1996, and the linear regression for DMSP-1999 with the urban population of 2000, is presented in figure 4. This result was obtained using the total number of urban population and night-time light pixel values for each AU.

To better observe the variability in the data for the AUs with urban populations of less than 400000 inhabitants, the capitals of the states (Cuiabá (MT), São Luís (MA), Belém (PA) and Manaus (AM)) were excluded in figure 4(b) and $(d)$. The capitals are special AUs because they encompass a large region and, consequently, a large number of districts (figure 5). This effect explained the higher urban population values for the AU containing Belém, whose urban population was lower (1271615 inhabitants) than the urban population registered for Manaus (1 394724 inhabitants) in the IBGE 2000 population census. The unit of Belém included several districts, including Barcarena, Mosqueiro, Castanhal and Murucupi, totalling 1918073 inhabitants as part of the urban population. On the other hand, the unit containing Manaus just included Iranduba totalling 1406708 inhabitants.

The coefficient of determination values $\left(R^{2}\right)$ obtained for the linear regression analysis indicated a linear relation between the night-time lights and the urban population. Even excluding the extreme values from the capitals, when the data dispersion was analysed, the $R^{2}$ values $\left(R^{2} \geqslant 0.82\right)$ were lower but still comparable to those obtained by other authors (Sutton et al. 1997, Elvidge et al. 2001a, Amaral et al. 2005). The $F$ values from the variance analysis of the regressions (table 2) confirmed the linear relations. High root-mean-square error (rms) values were 

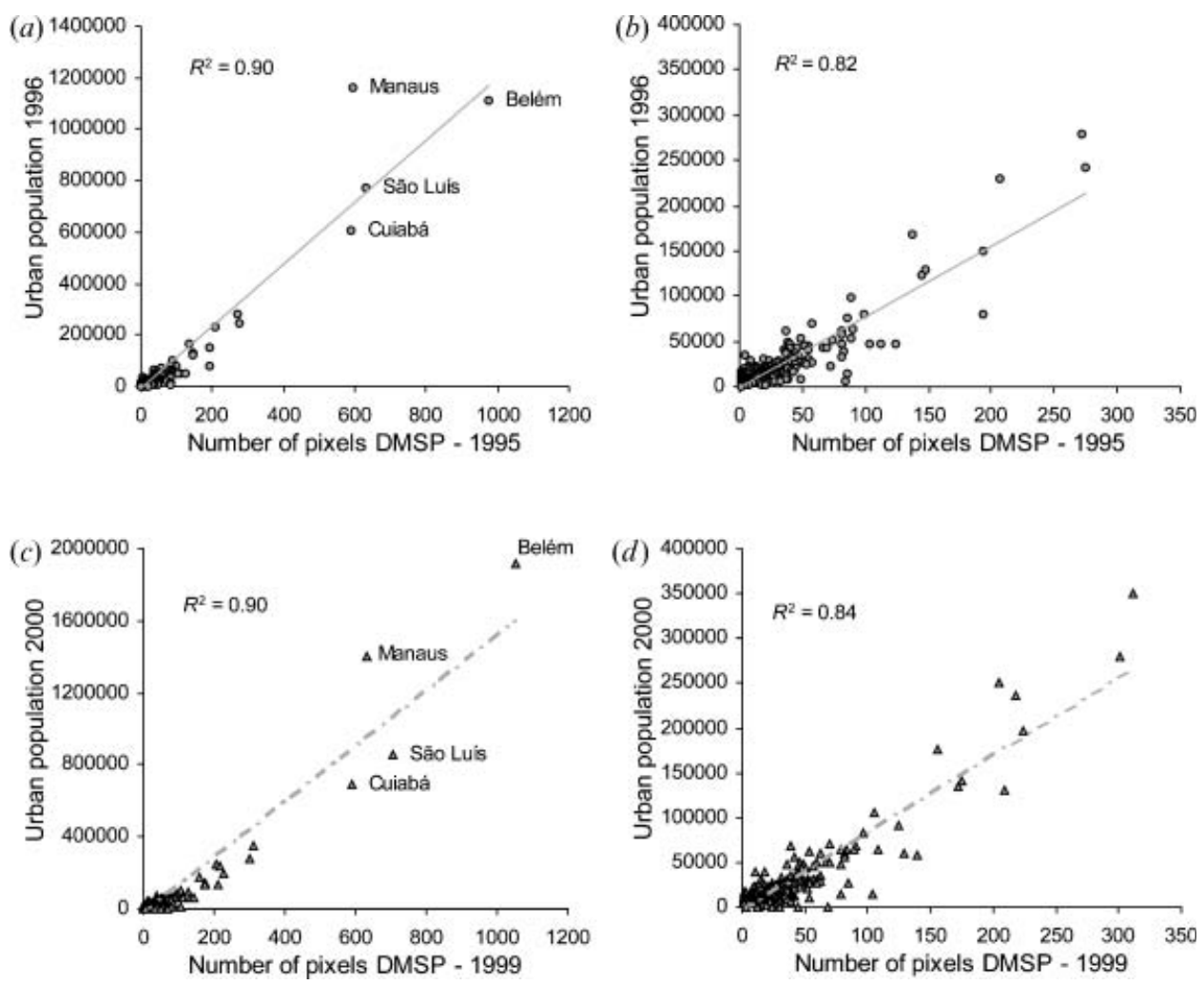

Figure 4. (a), (b) Relations between DMSP-1995 and the urban population of 1996. $(c),(d)$ Relations between DMSP-1999 and the urban population of 2000. Analytical units containing the capitals Cuiabá (MT), São Luís (MA), Belém (PA) and Manaus (AM) were excluded in (b) and $(d)$.

obtained due to the range of urban populations, varying from 77 to 1918073 inhabitants.

The urban population was estimated for 2003 from the linear equation that related the DMSP-1999 mosaic and the urban populations for 2000 without the capitals (figure $4(d)$ ), using the DMSP-2002 mosaic. Although the $R^{2}$ values were lower when excluding the large cities, this equation was chosen because it takes into account the variability of most of the urban settlements in the Amazon region with urban populations of less than 400000 inhabitants. The scatterplot (figure 6) present errors when comparing the DMSP estimates with the urban population values predicted by the official demographic statistics from IBGE population projections (IBGE 2003).

The urban population estimated from the DMSP-2002 mosaic was overestimated compared with the IBGE-2003 population projection. This overestimation is even more frequent for locations where the urban population is less than 50000 inhabitants. The use of a linear equation from the DMSP-1999 mosaic to estimate urban population may be responsible for the overestimation. The DMSP-1999 mosaic image was generated from only 16 single images sensitive to cloud cover presence and with night-time light foci slightly smaller than the DMSP-2002 ones. While for DMSP-2002, 516 night-time lights foci were registered, with an average area of $40 \mathrm{~km}^{2}$, for DMSP-1999, only 243 night-time light foci were identified with an average area of $37 \mathrm{~km}^{2}$. 


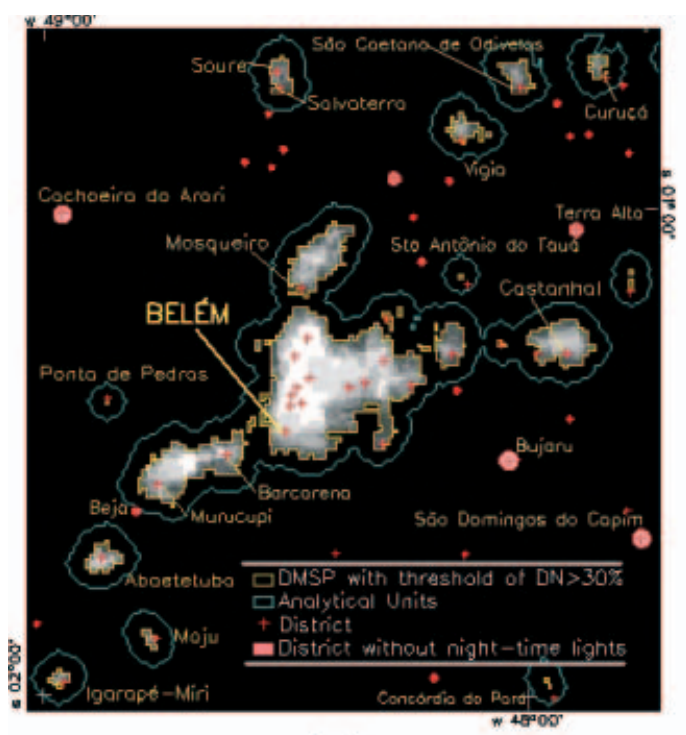

(a)

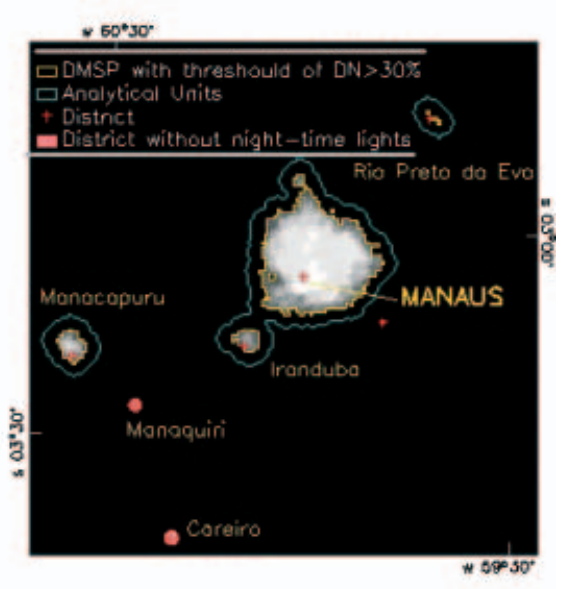

(b)

Figure 5. Analytical units over the Belém (a), and Manaus (b) metropolitan regions in the DMSP-2002 night-time light mosaic image.

The average population difference between DMSP-2002 estimates and IBGE2003 projections was 10332 inhabitants, for the 428 analysed locations. These locations had an average of 20481 inhabitants projected as urban population for 2003. For the cities with more than 150000 inhabitants, only for Santarém was the urban population projection higher than the tendency obtained from the night-time light foci, even though the night-time light focus had been enlarged from 156 to 168 pixels from the 1999 to the 2002 period.

A more effective validation for the night-time lights and urban population relations would be obtained with census data for urban populations, instead of using the available urban population statistical projection. The national census occurs at a 10 -year interval. Although a sample is taken annually (PNAD - the National Home Survey Sample), it is restricted to the principal metropolitan regions and the Amazon region is excluded.

Table 2. Linear regression variance analysis comparing DMSP night-time light pixels and urban populations.

\begin{tabular}{lccccc}
\hline & \multicolumn{2}{c}{ DMSP $1995 \times$ Population 1996} & & \multicolumn{2}{c}{ DMSP $1999 \times$ Population 2000} \\
\cline { 2 - 3 } \cline { 5 - 6 } & With capitals & Without capitals* & & With capitals & Without capitals* \\
\hline$R^{2}$ & 0.9 & 0.81 & & 0.9 & 0.84 \\
$n$ & 248 & 244 & & 225 & 221 \\
$F$ & 2349.74 & 1077.61 & & 2047.32 & 1188.18 \\
$F_{\text {value }} P$ & $7.20 \mathrm{E}-128$ & $4.10 \mathrm{E}-91$ & & $2.30 \mathrm{E}-111$ & $2.00 \mathrm{E}-90$ \\
rms & 37230 & 14629 & & 55144 & 17366 \\
\hline
\end{tabular}

*Excluding the capitals Belém (PA), Manaus (AM), São Luís (MA) and Cuiabá (MT). 


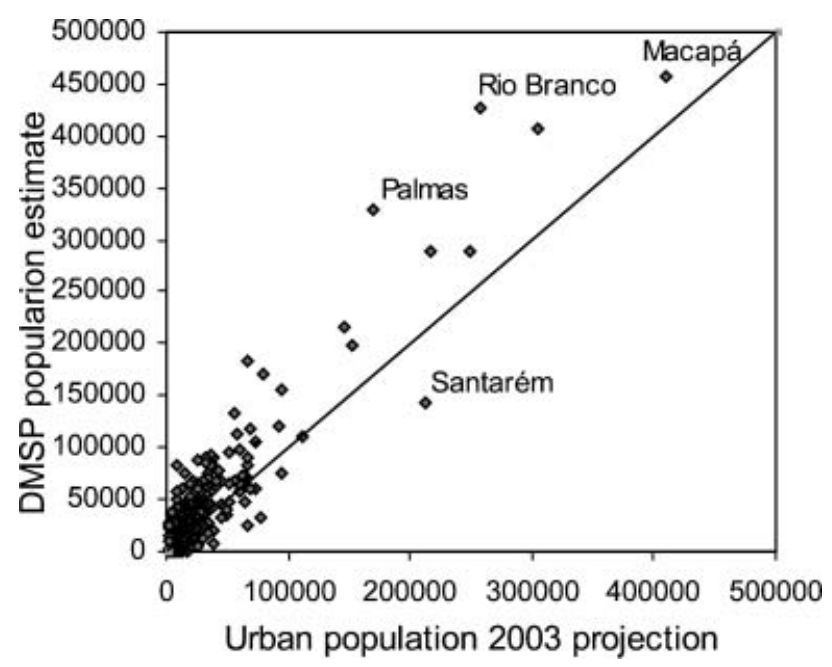

Figure 6. Scatterplot comparing urban population estimated from the DMSP-2002 mosaic image and from the IBGE-2003 urban population statistical projection.

\subsection{Fieldwork as a reference for analysis}

During the field campaign (15-30 May 2000), $551 \mathrm{~km}$ were investigated along the PA-150 highway from Belém to the city of Marabá in the state of Pará. Using GPS, the geographical coordinates of 49 human settlements were registered. Of these, 42 had public illumination, comprising seven cities, 26 villages and nine housing settlements. In another two villages and five housing settlements there was no public illumination. Observing the DMSP-2002 mosaic image, only the seven municipal centres (Abaetetuba, Moju, Tailândia, Goianésia do Pará, Jacundá, Nova Ipixuna, Marabá) and one village showed up in night-time lights. Most of these cities have the highway as their main street and urban development axis, as shown in figure 7(a). The village detected on DMSP-2002 mosaic is close to Marabá, the southeastern regional centre of Pará, and corresponds to the crossroads of the PA150 and Transamazônica highways, a highly illuminated place similar to that observed in Goianésia do Pará (figure 7(a)).

Analysis of the beginning and the end of public illumination within the urban area of the cities, registered by GPS coordinates (figure 7(b)), determined the correct position of nigh-time light foci, as observed in the DMSP-2002 mosaic. This result emphasizes the correspondence of DMSP night-time lights as indicators of urban spread.

When travelling across the Marabá rural area, a village called Brejo do Meio was visited. It is a settlement of about 2000 inhabitants, occupying an area of about $2.5 \mathrm{~km}^{2}$, with some basic urban infrastructure such as streets, public squares, schools, churches and external public illumination. However, there was no evidence of night-time lights for Brejo do Meio on the DMSP-2002 mosaic. This result suggests that night-time lights are registered on DMSP mosaic images for urban areas with a surface area greater than the one observed for this village.

\section{Conclusions}

This paper analysed the potential of DMSP night-time lights mosaic images to identify human presence and to estimate urban population in the Brazilian Amazon 


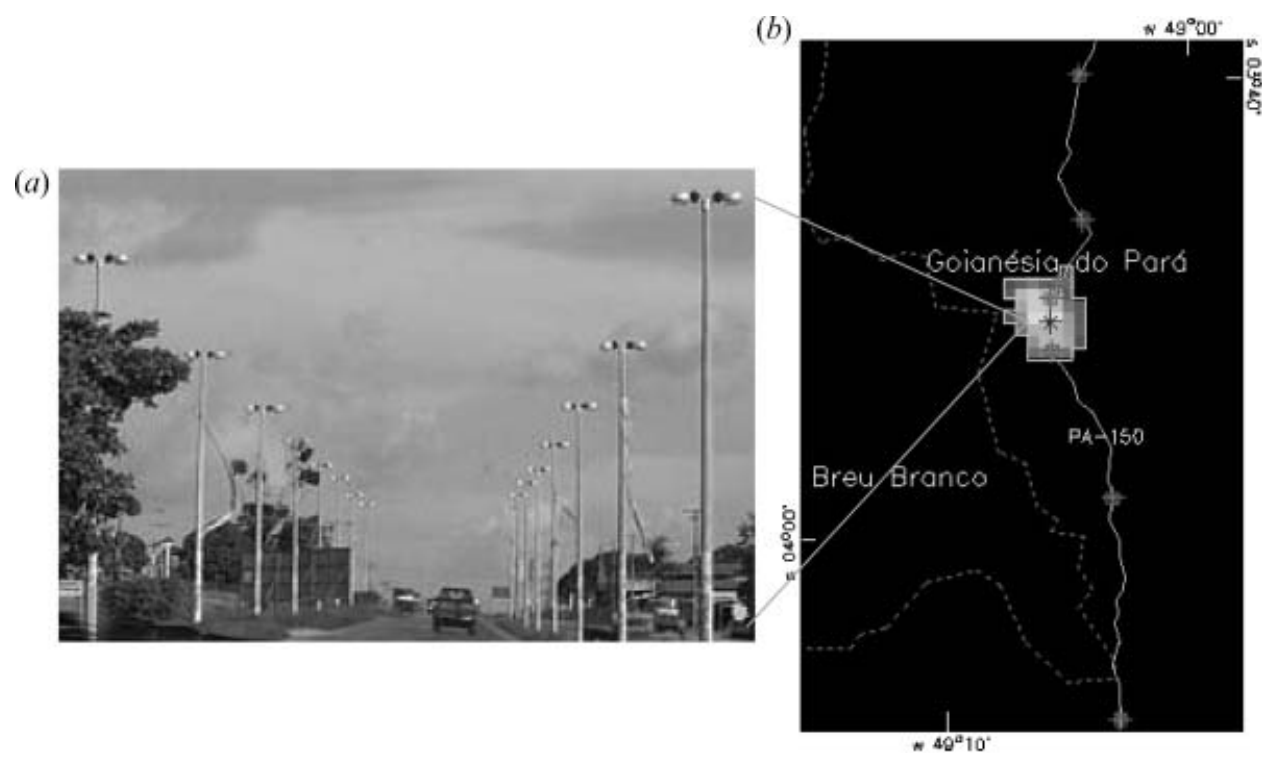

Figure 7. (a) Public illumination in the city of Goianésia do Pará, PA. (b) DMSP-2002 mosaic image and the field trajectory. Points along the PA-150 highway correspond to populated places.

region. To achieve this goal, a DMSP mosaic image for 2002 was generated, using a 6-month time interval, and minimizing the presence of ephemeral lights, i.e. forest fires, in the Amazon region. This procedure was essential for the proper identification of night-time lights emitted from human settlements.

The analytical units, defined as buffer zones from DMSP-2002 night-time light foci, enabled the comparison between frequency of night-time light pixels and urban population values. All urban settlements with populations greater than 10000 inhabitants were precisely detected by DMSP night-time lights. Most $(85 \%)$ of the settlements with a population between 5000 and 10000 inhabitants were identified with night-time lights. And some small settlements, with urban populations of less than 5000 inhabitants, were detected by DMSP image data.

The results from the linear regression, with coefficients of determination higher than 0.8 , indicated the potential utility of night-time lights to estimate urban populations in the Amazon region. The simplicity of the linear model, and the errors between urban population estimated by DMSP data and IBGE projection values (an average of 10332 inhabitants), recommend the use of DMSP image data to monitor the evolution of urban populations in settlements with more than 50000 urban inhabitants. For this purpose, some additional calibration with actual census data would confer more confidence on the linear model.

The fieldwork data showed the limitations of DMSP night-time light mosaics for detecting small settlements with modest urban infrastructure: DMSP image data could only detect settlements with more than $2.5 \mathrm{~km}^{2}$ of well-lit area. However, the fieldwork attested to the precise location and the boundaries of the night-time light foci. This result, in addition to the fact that DMSP night-time lights can be a reference for urbanized areas (Amaral et al. 2005), indicates the use of night-time lights as ancillary data to study the spatial distribution of the urban population in the Amazon region. 


\section{Acknowledgements}

The authors would like to thank the National Geophysical Data Center's Solar Terrestrial Physics Division (NGDC/STP) by the DMSP single orbits, the Instituto Brasileiro do Meio Ambiente e dos Recursos Naturais Renováveis (IBAMA) for providing the preprocessed images, and Dr. Yosio Shimabukuro for suggestions and text review.

\section{References}

Amaral, S., 2003, Geoinformação para estudos demográficos: Representação Espacial de Dados de População na Amazônia Brasileira. Tese de Doutorado, Escola Politécnica da USP, Universidade de São Paulo.

Amaral, S., Câmara, G., Monteiro, A.M.V., Quintanilha, J.A. and Elvidge, C.D., 2005, Estimating population and energy consumption in Brazilian Amazônia using DMSP night-time satellite data. Computers, Environment and Urban Systems, 29, pp. 179-195.

Ballester, M.V.R., Victoria, D.D.C., Krusche, A.V., Coburn, R., Victoria, R.L., Richey, J.E., Logsdon, M.G., Mayorga, E. and Matricardi, E., 2003, A remote sensing/GIS-based physical template to understand the biogeochemistry of the JiParaná river basin (Western Amazônia). Remote Sensing of Environment, 87, pp. 429-445.

BECKER, B.K., 1995, Undoing myths: the Amazon-an urbanized forest. In Brazilian Perspectives on Sustainable Development of the Amazon Region. Man and Biosphere Series, G.M. Clüsener and I. Sachs (Eds), pp. 53-89 (Paris: UNESCO and Parthenon Publishing).

BeCKer, B.K., 1998, A Especificidade do Urbano na Amazônia: desafios para políticas Públicas Consequentes. Estudo elaborado para a Secretaria de Coordenação dos Assuntos da Amazônia Legal-Ministério do Meio Ambiente (Rio de Janeiro: Ministério do Meio Ambiente).

BeCKer, B.K., 2001, Revisão das políticas de ocupação da Amazônia: é possível identificar modelos para projetar cenários? (preliminary version) (Rio de Janeiro: Laboratório de Gestão do Território/UFRJ).

Browder, J.O. and Godfrey, B.J., 1997, Rainforest Cities: Urbanization, Development, and Globalization of the Brazilian Amazon (New York: Columbia University Press).

CPTEC/INPE, 2003, The Large Scale Biosphere-Atmosphere Experiment in Amazonia (LBA). http://lba.cptec.inpe.br/lba/indexi.html.

Croft, T.A., 1973, Burning waste gas in oil fields. Nature, 245, pp. 375-376.

Croft, T.A., 1978, Nighttime images of the earth from space. Scientific American, 239, pp. 86-98.

Dobson, J.E., Bright, E.A., Coleman, P.R., Duree, R.C. and Worley, B.A., 2000, LandScan: a global population database for estimating populations at risk. Photogrammetric Engineering and Remote Sensing, 66, pp. 849-857.

Doll, C.N.H., Muller, J.P. and Elvidge, C.D., 2000, Night-time imagery as a tool for global mapping of socioeconomic parameters and greenhouse gas emissions. AMBIO, 29, pp. 157-162.

Durieux, L., Machado, L.A.T. and Laurent, H., 2003, The impact of deforestation on cloud cover over the Amazon arc of deforestation. Remote Sensing of Environment, 86, pp. 132-140.

Elvidge, C.D., Baugh, K.E., Kinn, E.A., Kroehl, H.W. and Davis, E.R., 1997a, Mapping city lights with nighttime data from the DMSP Operational Linescan System. Photogrammetric Engineering and Remote Sensing, 63, pp. 727-734.

Elvidge, C.D., Baugh, K.E., Hobson, V.H., Kinn, E.A., Kroehl, H.W., Davis, E.R. and Cocero, D., 1997b, Satellite inventory of human settlements using nocturnal 
radiation emissions: a contribution for the global toolchest. Global Change Biology, $\mathbf{3}$, pp. 387-395.

Elvidge, C.D., Baugh, K.E., Kinn, E.A., Kroehl, H.W., Davis, E.R. and Davis, C.W., 1997c, Relation between satellite observed visible-near infrared emissions, population, economic activity and electric power consumption. International Journal of Remote Sensing, 18, pp. 1373-1379.

Elvidge, C.D., Hobson, V.H., Nelson, I.L., Safran, J.M., Tuttle, B.T., Dietz, J.B. and BAUGH, K.E., 2001a, Global Observation of Urban Areas Based on Nocturnal Lighting (Boulder, CO: NOAA).

Elvidge, C.D., Imhoff, M.L., Baugh, K.E., Hobson, V.R., Nelson, I., Safran, J., Dietz, J.B. and TutTLE, B.T., 2001b, Night-time lights of the world: 1994-95. ISPRS Journal of Photogrammetry and Remote Sensing, 56, pp. 81-99.

FEARnSIDE, P.M., 2001, Saving tropical forests as a global warming countermeasure: an issue that divides the environmental movement. Ecological Economics, 39, pp. 167-184.

Foster, J.L., 1983, Observations of the Earth using nighttime visible imagery. International Journal of Remote Sensing, 4, pp. 785-791.

Frohn, R.C., McGwire, K.C., Dales, V.H. and Estes, J.E., 1996, Using satellite remote sensing to evaluate a socio-economic and ecological model of deforestation in Rondonia, Brazil. International Journal of Remote Sensing, 17, pp. 3233-3255.

Geist, H.J. and Lambin, E.F., 2001, What Drives Tropical Deforestation? A Meta-Analysis of Proximate and Underlying Causes of Deforestation Based on Subnational Case Study Evidence. International Project Office, LUCC Report Series no. 4 (Louvain-la-Neuve, Belgium: LUCC).

Henderson, M., Yeh, E.T., Gong, P., Elvidge, C. and Baugh, K., 2003, Validation of urban boundaries derived from global night-time satellite imagery. International Journal of Remote Sensing, 24, pp. 595-609.

IBGE, 2001, Censo Demográfico 2000 (Rio de Janeiro: Instituto Brasileiro de Geografia e Estatística).

IBGE, 2002, Estimativas populacionais do Brasil, grandes regiões, unidades da federação e municípios. Metodologia (Rio de Janeiro: Instituto Brasileiro de Geografia e Estatística).

IBGE, 2003, Estimativas das populações residentes, 2001 \& 2002. Available online at: http:// www2.ibge.gov.br/pub/Estimativas_Projecoes_Mortalidade_Populacao/.

Imhoff, M.L., Lawrence, W.T., Elvidge, C.D., Paul, T., Levine, E., Privalsky, M.V. and BRown, V., 1997b, Using nighttime DMSP/OLS images of city lights to estimate the impact of urban land use on soil resources in the United States. Remote Sensing of Environment, 59, pp. 105-117.

Imhoff, M.L., Lawrence, W.T., Stutzer, D.C. and Elvidge, C.D., 1997a, A technique for using composite DMSP/OLS 'City Lights' Satellite data to map urban areas. Remote Sensing of Environment, 61, pp. 361-370.

INPE, 2003, Monitoramento da floresta Amazônica Brasileira por Satélite Projecto PRODES. São Jasé dos Campos, Institute Nacional de Espaciais, 2003. Available online at: http://www.obi.inpe.br/prodes/.

McCracken, S., Brondizio, E., Nelson, D., Moran, E.F., Siqueira, A. and RodriguezPedrazA, C., 1999, Remote sensing and GIS at farm property level: demography and deforestation in the Brazilian Amazon. Photogrammetric Engineering and Remote Sensing, 65, pp. 1311-1320.

MCT, MDCET, 2003, Mosaico do Brasil. Available online at: http://www.dpi.inpe.br/ mosaico/.

Monte-Mór, R.L.M., 1998, Health, the environment and urban-rural relations in Amazonia. In Environment and Health in Developing Countries, M. Chatterji, M. Munasinghe and R. Ganguly (Eds), pp. 149-156 (New Delhi, India: APH Publishing).

MorAn, E.F. and BRONDIZIO, E., 1998, Land-use change after deforestation in Amazonia. In People and Pixel. Linking Remote Sensing and Social Science, D. Liverman, E.F. 
Moran, R. Rindfuss and P.C. Stern (Eds), pp. 94-120 (Washington, DC: National Academy Press).

Moran, E.F., Brondizio, E., Mausel, P. and Wu, Y., 1994, Integrating Amazonian vegetation, land use, and satellite data. Bioscience, 44, pp. 329-338.

Moran, E.F., Siqueira, A. and Brondizio, E., 2003, Household demographic structure and its relationship to the Amazon Basin. In People and Environment: Approaches to Linking Household and Community Surveys to Remote Sensing and GIS, J. Fox, V. Mishra, R. Rindfuss and S. Walsh (Eds), pp. 1-30 (Boston: Kluwer Academic Press).

Plutzar, C., Grübler, A., Stojanovic, V., Riedl, L. and Pospischil, W., 2000, A GISbased Approach for Modeling the Spatial and Temporal Development of Night-time Lights. Available online at: http://www.pph.univie.ac.at/vegoek/personal/plutzar/ a2000.html.

Potter, C., Davidson, E., Nepstad, D. and Carvalho, C.R., 2001, Ecosystem modeling and dynamic effects of deforestation on trace gas fluxes in Amazon tropical forests. Forest Ecology and Management, 152, pp. 97-117.

Revenga, C., Murray, S., Abramovitz, J. and Hammond, A., 1998, Watersheds of the World: Ecological Value and Vulnerability (Washington, DC: World Research Institute).

Roberts, D.A., Keller, M. and Soares, J.V., 2003, Studies of land-cover, land-use, and biophysical properties of vegetation in the Large Scale Biosphere Atmosphere experiment in Amazônia. Remote Sensing of Environment, 87, pp. 377-388.

SUDAM/PNUD, 2001, Diagnóstico e Cenarização Macrossocial da Amazônia Legal: Tendências Demográficas Recentes da Região Amazônica (Belém: Ministério da Integração Nacional).

Sutton, P., 1997, Modeling population density with night-time satellite imagery and GIS. Computer Environment and Urban Systems, 21, pp. 227-244.

Sutton, P., Roberts, C., Elvidge, C. and Meis, H., 1997, A comparison of nighttime satellite imagery and population density for the continental united states. Photogrammetric Engineering and Remote Sensing, 63, pp. 1303-1313.

Turner, A. and Openshaw, S., 2001, Disaggregative Spatial Interpolation. Available online at: http://www.geog.leeds.ac.uk/people/a.turner/publications/OpenshawTurner2001. html.

WelCh, R., 1980, Monitoring urban population and energy utilization patterns from satellite data. Remote Sensing of Environment, 9, pp. 1-9.

Welch, R. and ZuPKo, S., 1980, Urbanized area energy patterns from DMSP data. Photogrammetric Engineering and Remote Sensing, 46, pp. 201-207.

Wood, C.H. and Skole, D., 1998, Linking satellite, census, and survey data to study deforestation in the Brazilian Amazon. In People and Pixel: Linking Remote Sensing and Social Science, D. Liverman, E.F. Moran, R. Rindfuss and P.C. Stern (Eds), pp. 70-93 (Washington, DC: National Academy Press). 
Copyright of International Journal of Remote Sensing is the property of Taylor \& Francis Ltd and its content may not be copied or emailed to multiple sites or posted to a listserv without the copyright holder's express written permission. However, users may print, download, or email articles for individual use. 
Copyright of International Journal of Remote Sensing is the property of Taylor \& Francis Ltd and its content may not be copied or emailed to multiple sites or posted to a listserv without the copyright holder's express written permission. However, users may print, download, or email articles for individual use. 